\title{
SENIOR THEATRE AN IMPORTANT PART OF SENIOR CULTURE
}

\author{
ROSEMARIE KURZ \\ Faculty of Human Sciences, University of Graz, \\ Universitätsplatz 3, 8010 Graz, Austria \\ E-mail address: rosemariekurz@gmx.at
}

\begin{abstract}
The third age is an opportunity and can be used wisely. Going to university, travelling, volunteering or joining a theatre group could be possibilities. The article deals with Cultural Implications, and with senior theatre forging ahead in unexpected and adventurous directions. Last but not least, it deals with the situation of Senior Theatre in Graz, Austria.

Key words: demographic change, lifestyle, post-professional life, resource, mobility, acting, development, society, intergenerational, experiences, participation, volunteers, cultural implication
\end{abstract}

\section{INTRODUCTION: \\ THE WORLD OF THE SENIORS IS CHANGING}

Due to the demographic change many years of retirement may be used in a positive way being open for possibilities of a new culture of ageing. Medical, technical and social progress provide the means that more and more people can be older than 70 years nowadays. This is not only a European but also a global specific. In industrialized western countries a faster development is observable, yet in developing countries a trend towards longevity is recorded too. Elderly of the same life age may differ greatly in terms of their physical, mental and social capacities and resources and social norms and standards play an important role for the individual and the community. This phase of life can be designed and experienced in a positive or more negative attitude. It depends on the individual personality, the life biography, the living conditions and the social conditions (Kurz, 1999).

Social Gerontology sees itself as an integrated science accomplishing an essential contribution for understanding old age. This science deals with the description, explanation and modification of physical, psychological, social, historical and cultural aspects of ageing and age. Being old is not only associated with limitations and deficits. There are positive reserves. Only those who 
are evolving and so pursuing specific objectives, may affect the process or compensate for it, or do both. The post-professional life can be a meaningful phase of human life. Ageing is a lifelong process from birth to death. So a continuous development of the personality is possible (Baltes, 1994).

The third age in healthy conditions is a wonderful opportunity for subtle new challenges. It can be used wisely. It is desirable that this life phase is integrated into society. Rigid reversals of ageing should be broken. It should be possible that older people themselves decide whether to continue to work in their professions or to continue their education or just enjoy their free time filling it with things they never did before. This kind of "free time" should be filled by the individual and by offerings of communities. The latter are asked to provide various offers guaranteeing a higher quality of life in old age. Older people are very different. They are not a homogenous group and so accordingly to the current state of affairs society should offer a role diversity for persons in the post-employment phase of life.

Good ageing has its roots in earlier years of life and it depends on the financial, practical, spiritual and emotional resources of the individual. Mobility, friends, a good living place are personal prerequisites for activities outside the home like joining an institution for working as a volunteer or participating in a theatre group or whatever an older person may choose as leisure time activities (Kurz, 1999).

\section{CULTURAL IMPLICATIONS: OLDER GENERATIONS IN MODERN SOCIETIES}

"As long as culture is only seen as exceeding the limits of what is necessary or is defined as overcoming barbarism, whole groups of people will be excluded but also large areas of human behaviour will be excluded from cultural research" (Greverus, 1978). So if we think of seniors as having their own, direct contribution in the development of cultural inputs, new promising structures have to be developed so that they may prepare the bases for a new sustainable cultural development for older persons. People who developed skills in different special fields of knowledge in earlier life stages, will have the opportunity to be experts getting older. This expertise is not limited to professional knowledge, but includes also sound bases of practical life requirements. "It is necessary for the older people, that they do not only cherish their dreams of their past life and so get alienated from their everyday world, but that they set out to deal with themselves and their talents" (Hoffmann, 1988). If we give space to a cultural pluralism instead of talking about the subculture phenomena, the so-called "popular culture" could be explored in this context. Specific cultural research of the living conditions of older people is a great challenge for our modern society. A society not wanting to humiliate marginalized groups would be wise to create a basis for the integration of so-called "fringe groups", 
even if their everyday cultural manifestations do not comply with the standard (Kurz, 1993).

If we talk about different outputs of cultural topics we have to distinguish between an objective culture which means the totality of the creative possibilities being offered by the society as a cultural achievement of past generations whereas the subjective culture refers to the ability of socialized individuals to acquire the objective culture and by using their creativity enriching it. Individual biographies of older people living in a specific societal context are the basis for the advancement of the society (Hoffmann, 1988).

Simone de Beauvoir thinks that ageing within a stationary world, being anxious of one's development, are further ahead than those who started after it. "The ever-changing world and the understanding of life, plays an important role in the identity work of older people. Things are different in the turbulent world of today and the individual way is part of a social environment but doesn't coincide. This divergence works at the expense of the elderly" (Beauvoir, 1970).

Happiness and well-being might be achieved through cultural creativity by finding a way to get happiness in a changing world. A fulfilling life in older age does not mean perfect adaptation - full life consists of a perpetual struggle between various forces. One of these forces is the ability and the courage to change and look for answers for the contradictions of existence, because older people usually live in a demanding and challenging environment. Ursula Lehr notes that getting older is a continuation starting with the first day of life. Each stage of life requires a conversion to a new life and requires an adjustment and reorientation and in many cases means an abandonment of previous behaviour, responsibilities and rights. New settings must be recruited and such transformation is often experienced as a stress situation (Lehr, 1988).

Nowadays new promising structures have to be developed so that they may prepare the bases for a new sustainable cultural development in which the older generations are included. Cultural identity work is one of the most challenging works of the older individuals to be embedded in modern life. Synonymously the social status is particularly important to be able to have a good choice in post-employment and in the empty nest phase of life. These factors even have a crucial role for getting involved in cultural activities like participating in Seniors Theatre. New value orientation and cultural interactions mostly take place in groups with persons of similar educational and interest levels. Cultural identity work in ageing and social status are particularly important factors. These factors have a crucial role in challenging modern Seniors`s theatre. 


\section{THE AGE ADVANTAGE}

"Senior Theatre is forging ahead in unexpected and adventurous directions as there exists an 'Age Advantage for older actors. Acting of older persons starts to be an important factor in societies of the $21^{\text {st }}$ century. That means that more and more people are older than 60 and in good health. The baby boomer generation's first wave began turning 65 in 2011, and this will continue until 2029. As this generation got during their active life mostly everything they strove for, it is safe to say that they will make the best of their post professional life and bolster society with Culture concerning the big group of persons older than 60 and 65" (Bent, 2014).

\section{AGEING AND HEALTH: OLDER PERSONS ARE USING THE ADVANTAGES OF MODERN MEDICINE}

There is a remarkable growth of Senior Theatre in the western hemisphere especially in the USA. Older people nowadays are mostly healthier than previous generations, had a sounder education and a positive outlook on ageing. A Washington Study about connections between health and the arts found that especially acting in older age proved that seniors who participated in theatre work, lead healthier lives. Acting is a stimulus for the brain. This challenge supports the cognitive, emotional and physiological condition of an older person. Researchers proved in a study concerning seniors, that if they are involved in the arts they would have fewer falls, fewer doctor's visits and they take fewer medicines and their overall health condition would be better than those of the persons without such an engagement in the arts (Cohen et al., 2006).

\section{WORKING WITH SENIORS IS A CHALLENGE}

Older persons enjoying every day life not being troubled so much by daily inconveniences are to be found everywhere, where there is something for them to do, to learn, to experience, to be amongst other people, to travel, to play cards or just enjoying their grandchildren. Senior Theatre takes advantage of this attitude. A performer dealing with such an age group must be aware, that finding plays which will suit the actors will be appreciated by the audience and will be just right. Self-made plays by seniors might show low quality, or the existing literature might be not useable. So finding just the right literature and roles for a certain group will be rewarded but not be easy. Seniors are not always easy to deal with as they are used to doing things their own way. A specific difficulty will be to find the right person for a certain character of a play. There is often great jealousy among the older actors. But if the director or directness is able to master all these difficulties success will be theirs. 


\section{SENIOR THEATRE AND THE PERFORMERS, THE AUTHORS AND THE SENIOR ACTING GROUPS}

The success of a Senior Theatre Group is closely connected with the performers. Senior performers and senior actors range from professional to amateur in both rural and urban settings. The one thing performers must have and show is enthusiasm. Other talents are appreciated too - patience, humour, strength and time, lots of time and humour and patience again and sometimes strictness! Performers might have been in their younger year's performers themselves at public theatres or may never have done theatre performing or acting before and just want to have a new and a special challenge in their post-professional phase of life (e.g., "Senior theatre" n.d).

\section{THERE ARE SOME IMPORTANT ISSUES A PERFORMER HAS TO DEAL WITH}

One issueis findinganaccepted titlefor the group. This ishard work and needs a lot of discussions with all persons involved. Words like older people or seniors will not get high points. Even Golden or Silver will not be a good suggestion anymore. Authors of plays who deal with the life of older persons will be incomparable! The author has a world of opportunities - because: People who participate in Senior Theatre are pretty unique at the same time scriptwriters, directors and actors say that shows with modern, realistic themes are going to be popular (http://www.seniortheatre.com/bonnie-l-vorenberg/).

"Audiences-and, in particular, older theatregoers-want to see older adults in positive roles, whether it's having a new job or being sexually active!" (Abrahms, n.d.). And there is another advantage working with seniors. They have various abilities just waiting to be used by a performer or by the own family. So doing things for the group, for the actors is challenging and worthwhile.

\section{ADVANTAGES FOR THE ACTING SENIORS}

As acting might increase the mental possibilities, enhance self-esteem, support the elderly's relationships with those around them, it will be worthwhile to deal with all arising difficulties. Senior theatre provides older adults with an ideal opportunity to display their acting, singing, and dramatic talents. For some, it's an opportunity to revive and reprise their skills from bygone days. For others, it's the chance of a lifetime wish to take centre stage. They meet new people and enjoy the possibility doing something new. The greatest reward will be that older persons being open for new perspectives will be able to learn from other older persons, respect them and will be able to overlook each other`s oddities and sometimes strange behaviour (Worthington, n.d.). 


\section{MONEY AND SENIORS ACTING}

Most of the seniors being interested in acting will find a group they want to work with. It is generally known that nobody gets rich in acting in or with a seniors acting groups as donors for amateurs actors are hard to find. So mutual cooperation is asked for by the actors and by the performer. The performer and the crew must think about arising difficulties and find solutions. The first question will be, where can we perform without paying a lot of money? There is a broad variety of possibilities: small theatres of the community, senior centres, retirement homes, universities, social service organizations etc. Second question will be how will we pay for all additional issues like masks, costumes, stage props, lighting, layouts for flyers and posters and many more things? The answer may be simple as older people have talents in different branches of life and draw from lifelong experiences. Most of the actors may like to be useful. Older male adults are more or less enthusiastic about technical things and will therefore enjoy technics and could master this important branch" (e.g., "Senior theatre" n.d.).

\section{AGE AND THE THEMES OF PLAYS}

Senior theatre performers and actors range in age from 50 to 90 . The majority will be 60 to 75 . In Institutions with the very old persons actors could be older than 90. In Vienna in a nursing home a performer rehearsed the fairy tale Cinderella. This performance was very special. 12 actors brought on the stage more than 1000 years. They acted very smoothly and the stepmother had been friendly with Cinderella. The actors knew that if anything got wrong on stage, actors might get in great difficulties. Here you really could feel that the acting group is a family.

"Theatrical literature has mirrored the popular cultural views of how we see older adults: either as pathetic victims trapped in nursing homes or as super grannies surfing huge waves and running marathons" (Kandell, n.d.).

\section{SENIORS`ACTING MUST BE FUN}

Talking with older people about how they manage the status quo, you always hear "I only do things which are fun". Going to university, keeping an animal, playing with grandchildren, dancing, singing, sports or acting - the older persons want to have fun. This attitude might be hard for the performers in finding the right play which is not too long, not too short, a play for older audiences, or for very young people or just adapting a piece of literature anyhow the play must be challenging. Senior Theatre mostly works successfully, because it doesn't rely on set formulas or procedures. It can be drama or comedy, inexpensive or extravagant, a singing duo or, a play being read by the actors, but whatever a performer decides, it must be fun for the actors. 
Plays shouldn't be too difficult because that would require more rehearsals, and people will say: ^I' $m$ not doing this, because I have to have time for my duties as a granny for my daughter, so that she could stay in her employment, or I have appointments in the medical scene and so on «. But the plays can't be too easy either, because then actors won't be artistically challenged. Some companies have actors read their scripts on stage; others require them to memorize their lines. Or there is a combination of both (Kandell, n.d.).

\section{BENEFITS - MORE HAPPINESS THROUGH EDUCATION AND CULTURAL ACTIVITIES IN LATER LIFE}

Education in any form will add life to years and there is no limitation in what older persons can do. Taking up studies at universities, performing, acting, writing chronicles about their life, their ancestry, about their experiences in specific professional tasks or just writing plays which could be performed by fellow seniors and others (Worthington, n.d.).

\section{CREATIVE ACTIVITY OF SENIORS IN THE FIELD OF SENIOR THEATRE IN THE CITY OF GRAZ, AUSTRIA (Kurz, 1995 to 2007)}

GEFAS Steiermark 'Steirische Gesellschaft zur Förderung der Alterswissenschaften und des Seniorenstudiums` or Styrian Association for the Promotion of Social Gerontology and Senior Citizens Studies ' was founded in 1991 and was managed up to 2007 by Rosemarie Kurz. Between 1994 and 2002 GEFAS had been working hard to establish a Senior Theatre. It was a major effort as older people were not yet ready in Graz for this kind of educational program. GEFAS was only successful by getting public promotion and public attention.

\section{PERFORMANCES WITH OLDER PERSONS, MIGRANTS AND PERSONS WITH SPECIAL NEEDS}

Graz got a Senior Theatre Scene with a small group of Companies up to 2016. These Companies outgrew of the efforts of GEFAS Theatre. As long as GEFAS had been the leading organization various names were invented by an ever changing crew. Some of them wanted to do their own thing and new senior groups started. Sometimes these new groups vanished just as quickly as they appeared.

\section{HOW THINGS GOT STARTED IN GRAZ}

1993 Rosemarie Kurz attended a Performance of the Dortmund Senior Theatre "Jahrhundert Revue". She really and truly adored what she had experien- 
ced. So it was her great wish that there had to be a Senior Acting Group in Graz too. The idea was that an integrative, intergenerational Senior's Theatre modelled after the company "Jahrhundert Revue“ should be founded.

1994 GEFAS informed older people with a proclamation in the magazine "Young and Old" which had an edition of 20.000. "Join the fun of acting in a group! We deal with our experiences, our wisdom and life experiences and want to enjoy changing them into words, phrases and gestures!" There had only been one respondent! GEFAS tried again in 1995 and there was again only one respondent. Grete Kucera, a friend, was again interested. As Kurz had been engaged in managing all managing affairs of the institution, she asked the only one interested in Seniors Acting to get going. So the GEFAS Senior Theatre could get in starting position. One of the main targets was to interest not only older persons but young people and people with special needs as well.

1995 - The GEFAS - URANIA Theatre Group was established with 24 active members with different backgrounds and of all ages. The advantage of this cooperation had been that the Urania offered rehearsing rooms.

\section{WHAT HAD BEEN DONE BETWEEN 1994 AND 2006?}

An Animation Workshop with the directness Gerda Klimek and Fritz Holzer an actor from the Burgtheater got interested persons so that a permanent group could be established.

The 'Mezzanintheater Graz` wanted to encourage the senior actors to work with their own wisdom, life experiences and specific knowledge by transferring them into words, phrases and gestures. This workshop was the last effort for designing a Senior Theatre dealing with life experiences of older persons.

Jakob der Letzte by Peter Rossegger being adapted by Fred Strohmeier and directed by Gerda Klimek. This performance was first very successful performance open for the public.

1996 - A new Working Group was established and the members gave themselves a new name. The Theatre Chaots" were led by Barbara Schrempf. The working group found a consensus and started with two topics. Honour for men and work for women and Love in getting older.

1996 - Lysistrata by Aristophanes, rehearsed as a modern performance under the guidance of director James Karl Vogt, was another great success of the Gefas - Theater Group.

1997/98 Beate Zweydick of the Mezzanintheater was the directness of die Könniginnen von Frankreich and Das lange Weihnachtsmahl by Thornton Wilder.

2000 - Fritz Holzer offered another Workshop in Urania Graz.

2003-2006 The GEFAS - URANIA Theatre Group offered a continuing workshop.

ge-Facetten a new group performed a cabaret with older women at the Graz University for a Theatre congress. The directness was Barbara Schnepf. 
Die Bremer Stadt Senioren, an adaptation of Brüder Grimms Fairytales directed by Barbara Schnepf was a performance in which an older theatre audience could feel, understand and learn something about discrimination of older people.

Starting at 2000 there had been some spin-offs of actors and directors wanting to work according to their own ideas. Some of the actors alternated to the new offers concerning acting.

2000/2001 - Charly Vogt founded the theatre club Vorhang auf. This group broke up in 2002

2002 - Sternstunde was established with Barbara Schnepf as manager and some Senior Actors left the GEFAS - URANIA Theatre Group, who previously began their entertainment engagement with the efforts of GEFAS having up till now the responsibility working to get sponsoring from public institutions.

2007-2009 - The theatre group grau-meliert had been established with Barbara Schnepf at the Urania, an educational institution for adults.

\section{STERNSTUNDE THE ONLY SENIOR PERFORMING AND ACTING COMPANY IN GRAZ AT THE MOMENT}

Ursula Fiedler a retired lawyer is managing the group and she is responsible for the scripts of the plays which are being performed. A small group of theatre enthusiasts wanted to act in its own theatre club and so the theatre club Sternstunde was established in January 2002.

\section{URSULA FIEDLER STATES:}

"Nearly all of us were oldies and had acted at various amateur theatres in the past. Of course, we didn't know what it means to establish and lead our own theatre group but we had one thing in common: the wish of making theatre and acting together! So we jumped into the cold water and haven't regretted it until today. By dealing with theatre activities we have been motivated to activate and reactivate our creativity. These theatre activities gave us more self-confidence and vitality. Besides developing our acting skills at the performances we also focus on the social component. After rehearsals or performances we sit together in a relaxed atmosphere and discuss, listen, chat or simply enjoy being together. People get to know each other better, the acceptance between young and old people will be improved and friendships might arise. We also meet on a monthly basis even if there are no performances or rehearsals.

Moreover, we are proud that we have been quite successful in the past three years. Our performances were well attended and gained recognition so we may say that the development of our theatre group was excellent. In 2002 we started with 8 members. During the last 14 years many theatre enthusiasts 
have joined us, so that, at present we are an intergenerational group of about 30 members. Our website http://members.aon.at/sternstunde/ provides information about our theatre group, its members and information about our current production".

The Repertoire of Sternstunde between 2002 and 2015

2015 - Der tanz ums geld nach Ben Josans Volpone

2013 - Durch die finger g'schaut frei nach der Posse "Der Erbschleicher" von Johann N. Nestroy

2012 - Zwei ist einer zuviel frei nach dem Lustspiel Der Diener zweier Herren von Carlo Goldoni in einer Bearbeitung von Floris Gerber und Ursula Fiedler

2011 - Die kleinen verwandten frei nach Ludwig Thoma

2010 - Ein abend mit peter rosegger, szenische Lesung aus Werken von Peter Rosegger

2010 - Liebe, lügen, scherben frei nach dem Lustspiel Der zerbrochene Krug von Heinrich Kleist in einer Bearbeitung von Ursula Fiedler

2009 - Der habgierige und die liebe frei nach Der Geizige von Molière bearbeitet unter Verwendung des Originaltextes von Ursula Fiedler

2009 - Der vierfache schweinervekäufer (aus der Abelsberger Chronik von Peter Rosegger) für die Bühne eingerichtet von Sigmut Wratschgo, bearbeitet von Ursula Fiedler

2009 - Der habgierige und die liebe frei nach Der Geizige von Molière bearbeitet unter Verwendung des Originaltextes von Ursula Fiedler

2008 - Junggesellenglück frei nach der Posse Unverhofft von Johann N. Nestroy

2007 - Openhouse oder Das turbulente Wochenende Komödie von Barbara Schnepf. Der pensionierte Lord Reginald Openhouse hofft, dass seine Frau zu seinem 70. Geburtstag in die Toskana anreisen wir

2005 - Die krankheiten des herrn mimose Komödie frei nach Molière

2005 - Das liederliche kleeblatt nach der Zauberposse Der böse Geist Lumpazivagabundus von Johann Nepomuk Nestroy in einer Bearbeitung von $\mathrm{H}$. Mayer und U. Fiedler

2004 - Jubel; trubel und intrige eine Komödie frei nach William Shakespeare in einer Bearbeitung von tschouk.ent.kraim

2002 - Ein cocktail voller ueberraschungen ein Stück der Theaterwerkstatt tschouk. ent.kraim.

\section{SANDRA SCHÜDDEKOPF DIRECTNESS AND FREELANCER}

Abstract: Sandra Schüddekopf studied Theatre Science and North American Studies at the FU Berlin, while staging her first theatre productions. From 2001-2005 Assistant directress at the Burgtheater Vienna. Since 2007 freelancer directing at different theatres in Austria and Germany. Interested in stretching the boundaries of the Genre. Her work has been including: different gene- 
rations, biographical work, storytelling, participation and done projects on the verge of science and theatre. December 2015 one of her productions was played in Wrocław in the Oratorium Marianum "Unteilbar" - a play of the lives of Marie Curie, Lise Meitner and Hedy Lamarr.

\section{THEATRE WORK WITH PEOPLE BEYOND 50}

Theatre work with people beyond 50 is a possibility to connect generations and work on a very important subject: the social bond. With changing possibilities of people of no matter what age to participate in society the question of the social bond and the possibility of getting together of different generations apart from meeting in the family can be very enriching for all participants in these projects. It can alter their views of each other. Two projects of a theatre performing group uniT Graz (Retzhofer, 2016) were realized by the theatre directress Sandra Schüddekopf who dealt in different very interesting ways with these projects.

Forever young being produced in 2012 by uniT Graz was a project dealing with the questions: What is young? What is old? Why is youth so important in our society while there are more and more older people? How do we see these persons? Do we see them at all? What did the concept of ageing change? Is there a concept? What is it about ageing that we are afraid of?

This project was designed by involving people between the ages of 22 to 75. The "play" itself was developed by the actors using material they found themselves, fragments of fiction, as well as own experiences and biographical material. It was inspired by the production Kontakthof by Pina Bausch (http:/ / www.pinabausch.de/pina_bausch/index.php.) with seniors beyond the age of 65 trying to get in contact with the other sex in a dance hall. In the dance hall encounters were not only persons of different sexes but also pf different age. 16 individuals had diverse concepts of life.

Every actor / actress of this production dealt with questions concerning fear and ideas of how it is "getting old „or "staying young". They also dealt with their pictures and fears watching one another. So the involved group of 16 people learned something of the other actors and at the same time they learned from one another. Even though it was sometimes difficult for the directress to deal with these differences and abilities, these differences inspired all of them as well.

They became a kind of family without being in a family relationship. And of course they also discovered similarities. There was a dance rehearsal that took quite long. On the next day, the young ones complained about their muscle pains, the older Actors and Actresses arrived without complaints! But there was pain, of course! Not only their bodies but also their minds were challenged by the work.

Every one of them had their own difficulties regarding the work, no matter what age. Our actors / actresses that were beyond 50 had theatre experience. 
But they dreamed about a different way of rehearsing, of being present in the play, not only as a "character". They had to stretch their own boundaries of "the way I want it" because of the size of the group. At the end they all arrived at worshiping the others and respecting their needs and tics. Therefore this project was not only successful in questioning our pictures of age but also a social project in becoming a group, a very heterogeneous group following the goal to be together on stage relying on each other.

\section{INSTALLATION AS A FORM OF ACTING}

while this project focused on stories and pictures we have of youth and age in our society, another project on female stories based on the idea, that Austrian women in a certain age have similar experiences as young refugee women. Their encounter made it possible for both of them to talk about these experiences and transform them into a video installation. It was produced in a senior home with some of the inhabitants. This installation made the audience and the directness sit in front of women of different age and origin, while listening to their stories trying to match picture and story. The presentation mode was an installation, because almost none of the participants had any stage experience and the installation seemed to be a better way to play with the origins of the stories told.

Theatre projects with seniors and younger persons are a way of sharing their experiences and showing their diversity, their reality, and their specific abilities and changing by the same way the picture of people in their mind who are older or younger or just different in some way. They actresses and actors may become role models for living together in our changing societies.

A special present will be that we have the chance of going to be friends, another will be that the directresses might use such an experiment as an inspiration and the actresses and actors as well as the audience might get a voice beyond the storytelling patterns we are used to (Leidlmair, 2006).

\section{CONCLUSION}

Older persons nowadays may live 20 to 30 years after having been retired. This period of life might be a third of the whole life time. It is not just time, it is free time, it is time one has to fill with contents or learn to live without special contents, without a profession you might have loved, and without all the social contacts which made you this certain personality you enjoyed being up to now. So it might be important to create a new personality with new ideas, new perspectives. Doing so an older persons might start to take new interest in their biography, health, talents and start with an empowerment plan implying self-determination, the ability and the freedom to take responsibility for themselves in every aspect of life, to express own ideas, to 
initiate decisions and actively participate in modern life and on social politics at all levels.

Life long learning and learning in later life are specific challenges in getting older. Adult education is changing and there are different strands. One principle demands an exchange of political- and social knowledge, an orientation in social issues in order to allow self-reliant, democratic and solidary actions. In relation to the old forms of education we could speak of empowerment and competence. Older persons shouldn't just deal with their past and loose connection to the everyday life. They should stay interested in themselves and the practical outputs of our modern society. Older persons may learn how to be part of it in order to find a role in which he finds himself in this exciting new world. Seniors Theater is one possibility for finding this place.

\section{REFERENCES}

[1] Abrahms, S. (n.d.) Senior Theatre. Retrieved January 24, 2016, from http://www.wsj.com/articles/older-actors-are-taking-to-the-stage-1426475066 2015.

[2] Baltes P. M., \& Baltes, M. M. (1994). Gerontologie: Begriff, Herausforderung und Brennpunkte . In: P. B. Baltes, J. M. Mittelstraß, \& U. M. Staudinger (Eds.), Alter und Altern:Ein interdisziplinärer Studientext zur Gerontologie [Old age and ageing: An interdisciplinary reader in gerontology]. Berlin: de Gruyter.

[3] Bent, E. (2014). How Senior Theatre Is Forging Ahead. Retrieved from http:/ / www.americantheatre.org/2014/04/02/how-senior-theatre-is-forging-ahead.

[4] Beauvoir, S. de. (1989). Das Alter [The Coming of Age], Reinbek bei Hamburg: Rowohlt.

[5] Cohen, G. D., Perlstein S., Chapline J., Kelly J., Firth K. M., \& Simmens, S. (2006). The Impact of Professionally Conducted Cultural Programs on the Physical Health, Mental Health, and Social Functioning of Older Adults. The Gerontologist by The Gerontological Society of America, 46(6), 726734. doi: 10.1093/geront/46.6.726.

[6] Greverus, I. M. (1978). Kultur und Alltagswelt. Eine Einführung in Fragen der Kultur Anthropologie [Culture and everyday life. Introduction to cultural anthropology]. München: Beck Greverus.

[7] Hofmann, H. (ed.). (1998). Jugendwahn und Altersangst. Frankfurt am Main: Athenäum.

[8] Kandell, S., (n.d.). Stuart Kandell, PhD. Retrieved January 21, 2016, from http://www.creativeaging.org/programs-people/speaker/stuart-kandell-phd.

[9] Kurz, R. (1993). Weiterbildung in der Zweiten Lebenshälfte - Kultureller Standort - Kulturelle Veränderung, Diplomarbeit, Universität Graz.

[10] Kurz, R. (1999). Chancen und Möglichkeiten gesellschaftspolitischer Partizipation älterer Frauen und Männer in steirischen Seniorenorganisationen zwischen Anspruch und Wirklichkeit].. Institut für Sozial- und Wirtschaftswissenschaften an der Karl-Franzens-Universität Graz.

[11] Kunstlabor Graz (n.d.). Retrieved January 24, 2016, from http://www.uni-t.org/kunstlabor/.

[12] Kurz, R., Managing notes of GEFAS between 1995 and 2007.

[13] Leidlmair, K. (2006). Storytelling. Retrieved January 24, 2016, from https://www.uibk.ac.at/ psychologie/mitarbeiter/leidlmair/storytelling.pdf.

[14] Pina Bausch, (n.d.). Retrieved January 24, 2016, from: http://www.pinabausch.de/pina_ bausch/index.php.

[15] Senior theatre. (n.d.) In Wikipedia. Retrieved February 29, 2016, from https:/ / en.wikipedia.org/ wiki/Senior_theatre.

[16] Vorenberg, B. L. (n.d.). Senior Theatre, Ressource Centre. Retrieved January 29, 2016, from http:// www.seniortheatre.com/bonnie-l-vorenberg/.

[17] Worthington, B., \& Bernstein, A. (n.d.). Curtain Call - Senior Theater's Dramatic_Growth. Retrieved January 21, 2016, from http://www.todaysgeriatricmedicine.com/news/story2.shtml 